
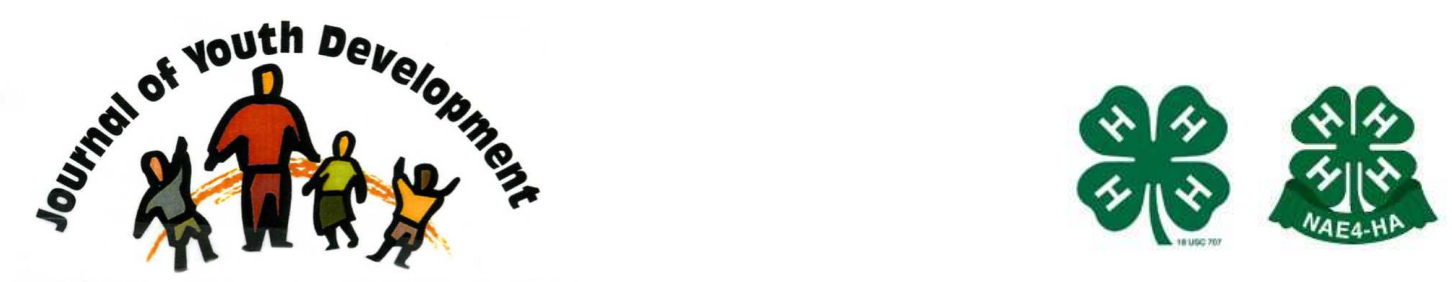

Bridging Research \& Practice

\title{
Together for a Better Education Program (Juntos Para Una Mejor Educación)
}

\author{
Tracy R. Martz \\ 4-H Youth Development \\ Douglas County Extension \\ Oregon State University \\ Roseburg, OR \\ tracy.martz@oregonstate.edu \\ Jeremy W. Green \\ 4-H Youth Development \\ Crook County Extension \\ Oregon State University \\ Prineville, OR \\ Jeremy.green@oregonstate.edu
}

Jamie M. Davis

4-H Youth Development

Lake County Extension

Oregon State University

Lakeview, OR

Jamie.Davis@oregonstate.edu 


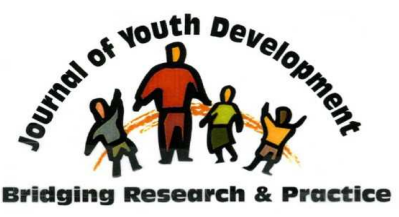

Volume 7, Number 2, Summer 2012
Article 120702RR001

\title{
Together for a Better Education Program (Juntos Para Una Mejor Educación)
}

Tracy R. Martz, Jeremy W. Green and Jamie M. Davis

\begin{abstract}
A new program entitled Together for a Better Education Program or Juntos Para Una Mejor Educación (2011) targets underserved and minority audiences to help build a stronger alliance with families, schools and community based youth serving agencies to help youth reach their goals for a rewarding future. The primary goal of the program is to allow the dream of college to be a reality for youth as well as their families. This six (6) session workshop series is designed so families and youth participate in activities and lessons congruently to develop and reach shared goals focused on graduating from high school and attending post-secondary education.
\end{abstract}

\section{Program Overview}

Together for a Better Education Program or Juntos Para Una Mejor Educación (2011) or simply titled "Juntos" is a program for 8 th- $12^{\text {th }}$ grade Latino and non-Latino youth and their families. Juntos provides information and resources to encourage families to work together to gain access to post-secondary education while preventing participants from dropping out of school. The need for programs like Juntos is ever-present when considering the national dropout rate of 16 through 24 year olds is $8.1 \%$ as of 2009 , and considerably higher (17.6\%) when singling out the Latino population.

Evaluation data collected from program participants (youth and adults) has revealed an increased understanding of graduation requirements, classes needed, higher education options, financial aid options and necessary tests needed to graduate and gain access to higher education. The "Juntos"program is currently being implemented in numerous states across the U.S. 


\section{Curriculum Highlights}

This curriculum stands out above other high school geared programs for its well designed, prescribed program that still allows room for customization to individual communities and audiences. The curriculum contains six, two and a half hour sessions spanning the following topics areas: making education a family goal, family and school communication, requirements for graduation, how to finance higher education, applying for college and creating a plan of action. The experiential activities throughout the sessions are pronounced for their ease of implementation and effectiveness in conveying the message or objective. Furthermore, it is important to indicate the resources provided by the authors to implement the program are extensive. Step-by-step program materials including curriculum, handouts, PowerPoint presentations and planning tools can be downloaded from the Juntos Program link on the NCfamilies.com website free of charge. The authors and creators have gone to great length to provide these resources in Spanish as well as English.

\section{Limitations}

It is notable that this curriculum was designed for audiences in North Carolina and that special attention must be made to update and address slides and handouts that present statistics and graduation requirements for specific communities and school districts.

\section{References}

Behnke, A., \& Aguilar, C. (2011). Together for a Better Education Program (Juntos Para Una Mejor Educación). Raleigh, NC. North Carolina State University Cooperative Extension. Retrieved December 5, 2011, from http://ncfamilies.com/juntos/

National Center for Educational Statistics. U.S. Department of Education. Retrieved from https://nces.ed.gov/fastfacts/display.asp?id=16

(C) Copyright of Journal of Youth Development $\sim$ Bridging Research and Practice. Content may not be copied or emailed to multiple sites or posted to a listserv without copyright holder's express written permission. However, users may print, download or email articles for individual use. 